\title{
TERT Gene
}

National Cancer Institute

\section{Source}

National Cancer Institute. TERT Gene. NCI Thesaurus. Code C18173.

This gene is involved in cell cycle regulation and telomere maintenance. 